\title{
BENEFICIAL EFFECTS OF GARLIC AND THYME POWDER ON PERFORMANCE AND CARCASS CHARACTERESTICS OF BROILER CHICKS
}

\author{
Manal K. Abou-Elnaga; G.A. Zanaty; A.M.H. Abou-Ashour and Mohamed F. A. Abdel- \\ Hafez. \\ Poultry Production Department, Faculty of Agriculture, Menoufia University, Shebin El-Kom, Egypt
}

(Received 10/12/2015, Accepted 7/6/2016)

\section{SUMMARY}

\begin{abstract}
$\mathrm{A}$ n experiment was conducted to investigate the effect of some herbal plant's powder; garlic (Allium sativum), thyme (Thyme vulgaris) and their mixture in broiler diets on growth performance, carcass traits, some blood components and economical efficiency. A total of 210 unsexed Arbor- Acers 1 day old broiler chicks were randomly distributed into 7 comparable groups, 30 chicks each. Each group was fed one of seven diets during the experimental period (from 1 to 35 days of age). Diet 1, control (with no garlic or thyme powder supplementation) while diets from $2-7$ contained garlic or thyme as follows: diet 2: control diet $+1 \%$ garlic; diet 3: control diet $+2 \%$ garlic; diet 4: control diet $+0.2 \%$ thyme; diet 5 : control diet $+0.4 \%$ thyme; diet $6:$ control diet $+1 \%$ garlic $+0.2 \%$ thyme; diet 7 : control diet $+2 \%$ garlic $+0.4 \%$ thyme. Results revealed that increasing dietary garlic or thyme significantly $(\mathrm{P} \leq$ 0.05 ) improved body weight (BW), body weight gain (BWG), performance index (PI) and feed conversion (feed/ gain). While, feed intake was significantly $(\mathrm{p} \leq 0.05)$ decreased with increasing dietary garlic or thyme. Also, water consumption and some blood serum components were significantly affected by the addition of garlic or thyme. Dressing percentage was not affected, while, lymphoid organs weight were significantly increased with increasing dietary garlic or thyme. Findings of this study indicate that broilers consuming control diet can achieve maximum performance and economic efficiency when supplemented with $0.4 \%$ thyme (group 5) without any side effects.
\end{abstract}

Keywords: Broiler, diet, garlic, thyme, performance, water consumption, carcass and serum parameters.

\section{INTRODUCTION}

Supplementing animal feeds with antibiotic- based growth promoters has been a common practice for many years (Wegener et al., 1999). It helps growing animals to efficiently digest their feed, derive maximum benefit from it and thereby allowing them to grow as strong and healthy individuals. Beneficial effects of bioactive plant substances in poultry nutrition may include the stimulation of appetite and feed intake, the improvement of endogenous digestive enzymes, secretion, activation of immune responses and antibacterial, antiviral and antioxidant actions (Toghyani et al., 2010). There is an increasing trend in the prevalence level of diseases, by industrialization of poultry science and breeding chickens in a large scale. To cope with this problem and improve the biological and nutritional characters of chickens, chemical compounds like antibiotic have been used highly in poultry industry (Lee et al., 2003). Unfortunately, over use of these products ended up with a lot of problems both for animals and costumers, for example, bacterial resistance to antimicrobial agents (Javed et al., 2006). Because of this problem, there have been made some restricted rules about the using of these antibiotics, like ban and low use of them (Kamel, 2001). Herbs have been used for some diseases since long time ago because of availability, easy usage, and non-side effects. Many herbs have a long history of use even prehistoric use, in preventing or treating human and animal diseases.

Phytogenic additives may have more than one mode of action, including improving feed intake and flavor, stimulating the secretion of digestive enzymes, increasing gastric and intestinal motility, endocrine stimulation antimicrobial, anti-viral, anthelminthic and coccidiostat activities, immune stimulation and anti- inflammatory and anti-oxidative activity and pigments (Kirkpinar et al., 2011). Garlic (Allium sativum) has been a subject of considerable interest as a medicine and therapeutic agent worldwide since ancient times. Main pharmacological effects of garlic are attributed to its organosulfur compounds (Tapiero et al., 2004). Allicin- the main bioactive component of garlic may account for some effects of 
garlic (Amagase et al., 2001). In vitro, studies have shown that garlic possesses antibacterial, antifungal, antiparasitic, antiviral (Ankri and Mirelman, 1999), antioxidant (Prasad et al., 1995), as well as antithermobotic, vasodilatory and anticancer (Agarwal, 1996) activities. It has benefit in lowering total plasma cholesterol, reducing blood pressure and decreasing platelet aggregation (Sterling and Eagling, 2001). Thyme (Thymus vulgaris) is a member of Lamiaceae family, with the main components phenols, thymol, (40\%) and carvacrol (15\%) (Mikaili et al., 2010). These herbs, also are traditionally used for several medicinal purposes: respiratory disease, anti-microbial, anti-nociceptive (Demir et al., 2008). Thymol and carvacrol are the main antibacterial active substances, so this plant can be used instead of commercial antibiotics. The beneficial value of thyme in poultry industry has been reported by (Demir et al., 2008). The objective of this study was to investigate the individual and combined effect of garlic or thyme on broiler performance, carcass characteristics and some blood parameters.

\section{MATERIALS AND METHODS}

The present study was conducted in a private Broiler Farm located at Shebin El kom, Menoufia Governorate, Egypt, in order to investigate the effect of supplementing broiler diets with some herbal plant's powder; garlic (Allium sativum), thyme (Thyme vulgaris) and their mixture, on the growth performance of broiler chicks, carcass traits and some serum components. Two hundred and ten one - day old, unsexed Arbor - Acres chicks were used in this experiment. Chicks were wing banded, weighed, and randomly allotted into seven treatment groups, 3 replicates of 10 chicks per each group. The National Research Council's nutrient values for ingredients (NRC, 1994) were used to formulate the basal diet (Tables 1 and 2). The experimental diets were designated as diets $\mathrm{T}_{1}, \mathrm{~T}_{2}, \mathrm{~T}_{3}, \mathrm{~T}_{4}, \mathrm{~T}_{5}, \mathrm{~T}_{6}$ and $\mathrm{T}_{7}$. Diet 1 ,

Table (1). Composition and chemical analysis of the experimental diets fed during starting (1 - 21) days of age.

\begin{tabular}{|c|c|c|c|c|c|c|c|}
\hline \multirow{2}{*}{ Ingredient } & \multicolumn{7}{|c|}{ Starter period } \\
\hline & $\mathrm{T}_{1}$ & $\mathrm{~T}_{2}$ & $\mathrm{~T}_{3}$ & $\mathrm{~T}_{4}$ & $\mathrm{~T}_{5}$ & $\mathrm{~T}_{6}$ & $\mathrm{~T}_{7}$ \\
\hline Ground yellow corn $(8.5 \%)$ & 49.72 & 47.86 & 46.65 & 48.82 & 48.69 & 48.07 & 44.52 \\
\hline Soybean meal (44\%) & 42.64 & 42.66 & 42.35 & 42.65 & 49.25 & 42.40 & 43.66 \\
\hline VegeTable oil & 4.34 & 4.88 & 5.4 & 4.55 & 4.56 & 4.99 & 6.00 \\
\hline Dicalcium phosphate & 1.1 & 1.1 & 1.1 & 1.1 & 1.1 & 1.1 & 1.1 \\
\hline Limestone, ground & 1.7 & 1.7 & 1.7 & 1.52 & 1.52 & 1.52 & 1.52 \\
\hline Vitamin and mineral mixture $^{1}$ & 0.3 & 0.3 & 0.3 & 0.3 & 0.3 & 0.3 & 0.3 \\
\hline Sodium chloride & 0.3 & 0.3 & 0.3 & 0.3 & 0.3 & 0.3 & 0.3 \\
\hline DL- methionine ${ }^{2}$ & 0.2 & 0.2 & 0.2 & 0.2 & 0.2 & 0.2 & 0.2 \\
\hline Garlic powder & --- & 1 & 2 & --- & --- & 1 & 2 \\
\hline Thyme powder & --- & --- & --- & 0.2 & 0.4 & 0.2 & 0.4 \\
\hline Total & 100 & 100 & 100 & 100 & 100 & 100 & 100 \\
\hline \multicolumn{8}{|l|}{ Calculated nutrient content ${ }^{3}$ : } \\
\hline Dry matter\% & 82 & 82 & 82 & 82 & 82 & 82 & 82 \\
\hline Crude protein, $\%$ & 22.96 & 23.00 & 22.94 & 22.94 & 22.94 & 22.92 & 22.99 \\
\hline $\mathrm{ME}, \mathrm{k}$ cal / $\mathrm{kg}$ diet & 2998 & 2997 & 2999 & 3003 & 3000 & 3002 & 2997 \\
\hline $\mathrm{C} / \mathrm{P}$ ratio & 130 & 131 & 131 & 132 & 132 & 132 & 130 \\
\hline Lysine, \% & 1.27 & 1.25 & 1.23 & 1.25 & 1.25 & 1.22 & 1.22 \\
\hline Methionine, $\%$ & 0.55 & 0.55 & 0.54 & 0.55 & 0.55 & 0.54 & 0.54 \\
\hline Calcium, \% & 0.98 & 0.98 & 0.98 & 1.00 & 1.00 & 1.00 & 1.00 \\
\hline Available phosphorous, \% & 0.53 & 0.52 & 0.52 & 0.52 & 0.52 & 0.51 & 0.51 \\
\hline \multicolumn{8}{|c|}{ 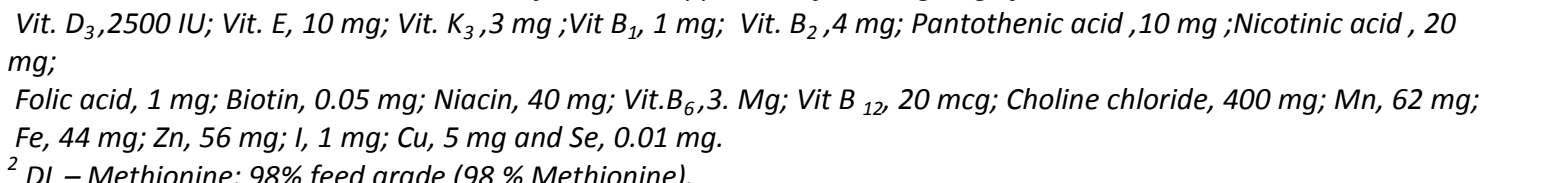 } \\
\hline
\end{tabular}


control (with no garlic or thyme powder supplementation) while diets from $\mathrm{T}_{2}-\mathrm{T}_{7}$ contained garlic or thyme as follows: $\mathrm{T}_{2}$ : control diet $+1 \%$ garlic; $\mathrm{T}_{3}$ : control diet $+2 \%$ garlic, $\mathrm{T}_{4}$ : control diet $+0.2 \%$ thyme; $\mathrm{T}_{5}$ : control diet $+0.4 \%$ thyme; $\mathrm{T}_{6}:$ control diet $+1 \%$ garlic $+0.2 \%$ thyme; $\mathrm{T}_{7}:$ control diet $+2 \%$ garlic $+0.4 \%$ thyme. Throughout the 5 - week experimental period, chicks were given feed and water $a d$ libitum. Florescent lights were used. Chicks were individually weighed weekly. Dietary composition and chemical analysis of the experimental diets are shown in Tables 1 and 2. Body weight, feed intake and water consumption of the birds were recorded weekly. Body weight gain, feed conversion, and economical efficiency were calculated. Performance index (PI) was calculated according to North, 1984. Where PI=live body weight $(\mathrm{kg}) \times 100 /$ feed conversion.

Table (2). Composition and chemical analysis of the experimental diets fed during growing periods (22-35) days of age.

\begin{tabular}{|c|c|c|c|c|c|c|c|}
\hline \multirow{2}{*}{ Ingredient } & \multicolumn{7}{|c|}{ Grower period } \\
\hline & $\mathrm{T}_{1}$ & $\mathrm{~T}_{2}$ & $\mathrm{~T}_{3}$ & $\mathrm{~T}_{4}$ & $T_{5}$ & $\mathrm{~T}_{6}$ & $\mathrm{~T}_{7}$ \\
\hline Ground yellow corn $(8.5 \%)$ & 57.78 & 56.30 & 55.35 & 57.26 & 56.97 & 55.71 & 53.97 \\
\hline Soybean meal (44 \%) & 35.36 & 35.29 & 35.09 & 35.52 & 35.48 & 35.36 & 35.31 \\
\hline VegeTable oil & 3.04 & 3.59 & 3.94 & 3.19 & 3.32 & 3.79 & 4.43 \\
\hline Dicalcium phosphate & 0.82 & 0.82 & 0.87 & 1.33 & 1.33 & 1.6 & 1.39 \\
\hline Limestone, ground & 2.2 & 2.2 & 1.95 & 1.7 & 1.7 & 1.54 & 1.7 \\
\hline Vitamin and mineral mixture $^{1}$ & 0.3 & 0.3 & 0.3 & 0.3 & 0.3 & 0.3 & 0.3 \\
\hline Sodium chloride & 0.3 & 0.3 & 0.3 & 0.3 & 0.3 & 0.3 & 0.3 \\
\hline DL- methionine ${ }^{2}$ & 0.2 & 0.2 & 0.2 & 0.2 & 0.2 & 0.2 & 0.2 \\
\hline Garlic powder & --- & 1 & 2 & --- & --- & 1 & 2 \\
\hline Thyme powder & --- & --- & --- & 0.2 & 0.4 & 0.2 & 0.4 \\
\hline Total & 100 & 100 & 100 & 100 & 100 & 100 & 100 \\
\hline \multicolumn{8}{|l|}{ Calculated nutrient content ${ }^{3}$ : } \\
\hline Dry matter\% & 82 & 82 & 82 & 82 & 82 & 82 & 82 \\
\hline Crude protein, $\%$ & 20.47 & 20.49 & 20.48 & 20.47 & 20.47 & 20.47 & 20.48 \\
\hline $\mathrm{ME}, \mathrm{k}$ cal / kg diet & 3002 & 3002 & 3000 & 3001 & 3000 & 3002 & 3001 \\
\hline $\mathrm{C} / \mathrm{P}$ ratio & 146.44 & 146.30 & 146.27 & 146.39 & 146.34 & 146.44 & 146.32 \\
\hline Lysine, \% & 1.15 & 1.12 & 1.12 & 1.15 & 1.14 & 1.12 & 1.09 \\
\hline Methionine, \% & 0.53 & 0.53 & 0.52 & 0.53 & 0.53 & 0.53 & 0.52 \\
\hline Calcium, $\%$ & 1.02 & 1.02 & 1.01 & 1.02 & 1.02 & 1.02 & 1.02 \\
\hline Available phosphorous, \% & 0.53 & 0.53 & 0.53 & 0.53 & 0.53 & 0.53 & 0.53 \\
\hline $\begin{array}{l}{ }^{1} \text { Vitamin and mineral mixture at } \\
\text { Vit. } D_{3}, 2500 \mathrm{IU} \text {; Vit. E, } 10 \mathrm{mg} \text {; Vit. } \\
\mathrm{mg} \text {; } \\
\text { Folic acid, } 1 \mathrm{mg} \text {; Biotin, } 0.05 \mathrm{mg} \text {; } \\
\mathrm{Fe}, 44 \mathrm{mg} ; \mathrm{Zn}, 56 \mathrm{mg} ; \mathrm{l}, 1 \mathrm{mg} \text {; Cu, } \\
{ }^{2} \mathrm{DL}-\text { Methionine: } 98 \% \text { feed grade } \\
{ }^{3} \text { Calculated according to NRC (19. }\end{array}$ & $\begin{array}{l}\text { of the diet } \\
\mathrm{ng} ; \mathrm{Vit} \mathrm{B}_{1} \\
40 \mathrm{mg} ; \mathrm{Vi} \\
\text { ind Se, } 0.0\end{array}$ & $\begin{array}{l}\text { upplies th } \\
\text { mg; Vit. } \\
B_{6}, 3 . \mathrm{Mg} ; \\
\mathrm{mg} .\end{array}$ & $\begin{array}{l}\text { following } \\
2,4 \mathrm{mg} ; \mathrm{P} \\
\text { 'it } B_{12}, 20\end{array}$ & $\begin{array}{l}\text { kg of the } \\
\text { tothenic } \\
\text { icg; Cholit }\end{array}$ & $\begin{array}{l}\text { liet: Vit. A, } \\
\text { cid } 10 \mathrm{mg} \\
\text { e chloride, }\end{array}$ & $\begin{array}{l}12000 \mathrm{IU} ; \\
\text { Nicotinic a } \\
400 \mathrm{mg} ; \mathrm{M}\end{array}$ & $\begin{array}{l}\text { cid , } 20 \\
, 62 \mathrm{mg} ;\end{array}$ \\
\hline
\end{tabular}

At 3 and 5 weeks of age, 6 chicks were randomly chosen and slaughtered to determine carcass traits; eviscerated carcass (without head, neck, and legs), total giblets (liver, gizzard and heart), total edible parts (carcass + total giblets) and their lymphoid organs (spleen, bursa of fabricius and thymus; all lobes from left side of the neck) were determined. Data obtained were used for the calculation of dressing percentage as follows: Dressing percentage $(\%)=$ carcass weight $\times 100 /$ live weight of bird. Blood samples were collected at slaughter time into non- heparinized tubes at 3 and 5 weeks of age from 6 birds of each treatment and the blood was centrifuged at $2000 \mathrm{rpm}$ for $15 \mathrm{~min}$ to obtain serum samples. Individual serum samples were analyzed for total protein (TP, g/dl), albumen (A, g/dl), globulin (G, g/dl), total cholesterol $(\mathrm{mg} / \mathrm{dl})$, serum aspartate aminotransferase (AST, U/L) and Alanine aminotransferase (ALT, U/L) enzymes. The economical efficiency was calculated from the input - output analysis (Heady and Jensen, 1954), assuming that other head costs were constant, as follows: [(price of kg weight gain feed cost $/ \mathrm{kg}$ gain)/feed cost $/ \mathrm{kg}$ gain $\times 100]$ under local conditions. Data were statistically analyzed by the completely randomized design using SPSS (2011) program and the differences among means were determined using Duncan's multiple range test (Duncan, 1955). Percentages were transformed to the corresponding arcsin values before performing statistical analysis: 
Abou-Elnaga et al.

$$
Y_{i j}=\mu+\alpha_{i}+E_{i j}
$$

Where: $Y_{i j}=$ an observation. $\mu=$ Overall mean. $\alpha_{i}=$ effect of treatment $(\mathrm{I}=1,2,3,4, \ldots . .7)$, and $E_{i j}=$ Random error.

\section{RESULTS AND DISCUSSION:}

\section{Growth performance:}

Tables (3 and 4) presents the mean \pm SE of body weight, body weight gain, performance index (PI), feed intake, feed conversion ratio and water consumption of broiler chicks fed garlic or thyme powder or their mixture supplementation at 3 and 5 weeks of age. At 3 weeks of age, the average body weight and body weight gain were significantly $(\mathrm{P} \leq 0.05)$ increased with herbal plants supplementation. The same trend was more pronounced at 5 weeks. In general, at 5 weeks of age; chicks fed the mixture of herbal plant $(0.2 \%$ garlic $+0.4 \%$ thyme $/ \mathrm{kg}$ diet, T7) had the heaviest body weight $(2204 \mathrm{~g} / \mathrm{chick})$ and the best total body weight gain ( $2164 \mathrm{~g} /$ chick) in comparison with (2109 and $2069 \mathrm{~g} /$ chick) with the control diet.

Table (3). Effect of dietary garlic and thyme powder supplementation on growth performance and performance index of broiler chicks at 3 and 5 weeks of age (Means \pm S.E).

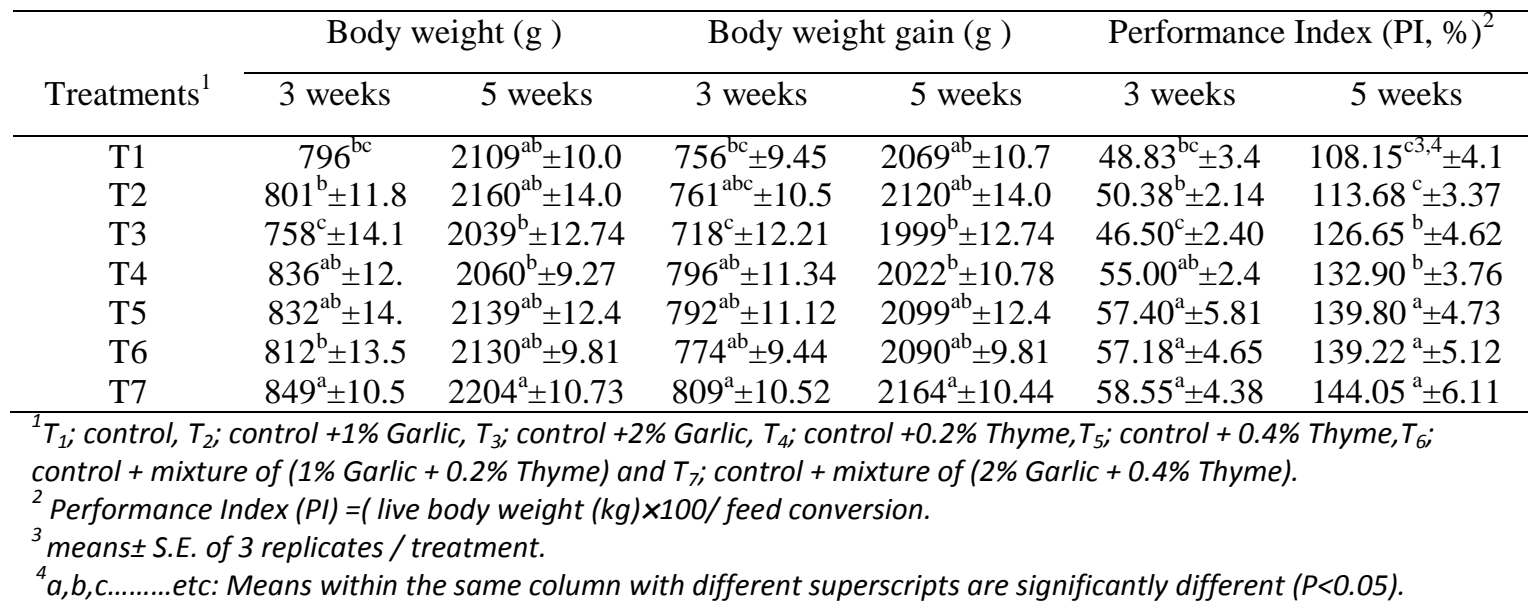

Table (4). Effect of dietary garlic and thyme powder supplementation on feed intake and feed conversion and water consumption of broiler chicks at 3 and 5 weeks of age (Means \pm S.E).

\begin{tabular}{ccccccc}
\hline & \multicolumn{2}{c}{ Feed Intake $(\mathrm{g} / \mathrm{b} / \mathrm{d})$} & \multicolumn{2}{c}{ Feed conversion ratio } & \multicolumn{2}{c}{ Water consumption $(\mathrm{ml} / \mathrm{b} / \mathrm{d})$} \\
\cline { 2 - 6 } Treatments $^{1}$ & 3 weeks & 5 weeks & 3 weeks & 5 weeks & 3 weeks & 5 weeks \\
\hline T1 & $55.00^{\mathrm{a}} \pm 0.02$ & $102.00^{\mathrm{a}} \pm 2.96$ & $1.52^{\mathrm{a}} \pm 0.0$ & $1.60^{\mathrm{a}} \pm 0.05$ & $71.00^{\mathrm{e}} \pm 00$ & $112.00^{\mathrm{b} 2,3} \pm 1.98$ \\
T2 & $51.00^{\mathrm{b}} \pm 0.02$ & $101.00^{\mathrm{a}} \pm 3.31$ & $1.42^{\mathrm{b}} \pm 0.0$ & $1.51^{\mathrm{ab}} \pm 0.05$ & $78.00^{\mathrm{c}} \pm 00$ & $119.00^{\mathrm{b}} \pm 2.46$ \\
T3 & $49.00^{\mathrm{b}} \pm 0.01$ & $84.00^{\mathrm{b}} \pm 2.98$ & $1.47^{\mathrm{a}} \pm 0.0$ & $1.41^{\mathrm{b}} \pm 0.06$ & $86.00^{\mathrm{a}} \pm 00$ & $127.00^{\mathrm{a}} \pm 2.48$ \\
T4 & $52.00^{\mathrm{b}} \pm 0.02$ & $86.00^{\mathrm{b}} \pm 2.91$ & $1.37^{\mathrm{b}} \pm 00$ & $1.36^{\mathrm{b}} \pm 0.05$ & $70.00^{\mathrm{f}} \pm 00$ & $111.00^{\mathrm{b}} \pm 2.93$ \\
T5 & $51.00^{\mathrm{b}} \pm 0.01$ & $85.00^{\mathrm{b}} \pm 3.07$ & $1.24^{\mathrm{c}} \pm 0.0$ & $1.34^{\mathrm{b}} \pm 0.05$ & $70.00^{\mathrm{f}} \pm 00$ & $111.00^{\mathrm{b}} \pm 5.50$ \\
T6 & $51.00^{\mathrm{b}} \pm 0.59$ & $83.00^{\mathrm{b}} \pm 3.45$ & $1.35^{\mathrm{b}} \pm 0.0$ & $1.33^{\mathrm{b}} \pm 0.06$ & $73.00^{\mathrm{d}^{\mathrm{b}} \pm 00}$ & $119.00^{\mathrm{b}} \pm 3.54$ \\
T7 & $52.00^{\mathrm{b}} \pm 0.01$ & $87.00^{\mathrm{b}} \pm 2.86$ & $1.33^{\mathrm{b}} \pm 0.0$ & $1.34^{\mathrm{b}} \pm 0.05$ & $81.00^{\mathrm{b} 2,3} \pm 00$ & $123.00^{\mathrm{a}} \pm 2.55$ \\
\hline
\end{tabular}

${ }^{1} T_{1} ;$ control, $T_{2}$; control $+1 \%$ Garlic, $T_{3}$; control $+2 \%$ Garlic, $T_{4} ;$ control $+0.2 \%$ Thyme, $T_{5} ;$ control $+0.4 \%$

Thyme, $T_{6} ;$ control + mixture of $(1 \%$ Garlic $+0.2 \%$ Thyme $)$ and $T_{7} ;$ control + mixture of $(2 \%$ Garlic $+0.4 \%$ Thyme $)$.

${ }^{2}$ means \pm S.E. of 3 replicates / treatment.

${ }^{3} a, b, c \ldots \ldots . . . . e t c:$ Means within the same column with different superscripts are significantly different $(P<0.05)$.

The smallest BWG was obtained with birds fed $2 \%$ garlic powder. This may attributed to the therapeutic potential of garlic low doses (1\%) against ulcers (Adeniyi et al. 2006). These improvements in BW suggest that garlic can improve productive performance of broiler chicks. It has been used for about 50 years as antibiotic growth promoters. 
Performance index (PI) at 3 and 5 weeks was significantly $(\mathrm{P} \leq 0.05)$ increased with the increase of dietary supplementation. These results support the findings of Bolukbasi et al. (2006), Mansoub and Myandoab (2011), Elagib et al. (2013) and Saeid et al. (2013), who found that herbal plants mixture can improve productive performance because of its anti - biotical potential, hypocholestermic effects and growth promoting.

The effect of dietary garlic and thyme powder and their mixture supplementation on feed intake (FI), feed conversion ratio (FCR) and water consumption (WC) are presented in Table (4). At 3 weeks of age, chicks fed $2 \%$ garlic powder (T3) diet had the lowest FI (49 g/ chick/ d) compared to those fed the control $\operatorname{diet}(55 \mathrm{~g} / \mathrm{chick} / \mathrm{d})$, feed intake in other treatments was not significantly affected.

In general, at 5 weeks of age, there were significant differences in FI throughout the entire experimental period (0-5 weeks) except treatment $\mathrm{T}_{2}(1 \%$ garlic, $101 \mathrm{~g} / \mathrm{b} / \mathrm{d})$ compared to the control treatment $(102 \mathrm{~g} / \mathrm{b} / \mathrm{d})$. Our results with respect to FI revealed that the feed intake was decreased with increasing garlic levels, coinciding with results of Javandel et al. (2008) who reported that feed intake was significantly higher for birds fed diets with lower concentration of garlic 0.125 and $0.250 \%$ compared to higher level $0.50,1$ and $2 \%$.

Differences in FI between treatments derived from that herb had the ability to change feed intake and could be successfully used as growth promoters (Hertrampf, 2001 and Bolukbasi et al., 2006). Results reported herein are in agreement with those obtained by Demir et al. (2008), Onibi et al. (2009), Fadlalla et al. (2010), Ao et al. (2011), Toghyani et al. (2011), Elagib et al. (2013), Saeid et al. (2013)and Kirkpinar et al. (2014), who noticed that there were no significant differences between treatments $(0.5 \%$ garlic powder or $0.5 \%$ black seed and their mixture) in feed intake and the control treatment.

On the other hand, Kumar et al. (2005), Bolukbasi et al. (2006), Afsharmanaesh et al. (2008), Raeesi et al. (2010) and Mansoub and Nezhady, (2011) concluded that feed intake was progressively increased by garlic or thyme supplementation (1.5\% Nettle, $1.5 \%$ thyme, $1.5 \%$ garlic, $1.5 \%$ Nettle and thyme, $1.5 \%$ Nettle and garlic, $1.5 \%$ thyme and garlic and $1.5 \%$ of Nettle, thyme and garlic).

The average feed conversion ratio (FCR) at 3 weeks of age was significantly $(\mathrm{P} \leq 0.05)$ improved with the addition of (1\%) garlic and thyme either single or mixed compared to the control group in comparison with the control group and chicks fed $2 \%$ garlic. Data in Table (4) showed that FCR at 5 weeks was not significantly different between all treatments fed garlic or thyme supplementation in comparison with the control treatment. The same trend was more obvious at (0-5) weeks. The same trend was observed by Fadlalla et al. (2010), Najafi and Torki (2010), Raeesi et al. (2010), Elagib et al. (2013), and Tabari et al. (2013) who found better FCR with garlic or thyme supplementation to broiler diets.

The average water consumption at 3 and 5 weeks of age was significantly $(\mathrm{P} \leq 0.05)$ increased with both garlic supplementation ( 1 and $2 \%$ ) compared to the control diet. The highest water consumption was attained with groups fed $2 \%$ garlic powder either single or in a mixture. Meanwhile, the lowest water consumption was found with thyme (0.2 and 0.4 supplementation). Average water consumption was significantly $(\mathrm{P} \leq 0.05)$ decreased with thyme supplementation in comparison with the control group.

These results agree with Rahardja et al. (2010) who found that water intake was increased when older chickens fed diets with 1,2 and 4\% garlic, but younger birds remained unaffected.

On the contrary, Aji et al. (2011) found that the highest dose (100 mg) of onions significantly $(\mathrm{P} \leq$ 0.05 ) increased water composition of birds whereas onion at 25 and $50 \mathrm{mg}$ and garlic at all dose regimens $(25,50$ and $100 \mathrm{mg})$ did not affect bird's water compassion. This increase in water intake of birds may be as a result of the direct consequence of increase garlic levels in their feed intake.

\section{Carcass characteristics:}

Experimental results of garlic (1 and $2 \%)$ or thyme $(0.2$ and $0.4 \%)$ powder or their mixture supplementation on carcass characteristics at 3 and 5 weeks of age are presented in Tables (5 and 6).

At 3 weeks of age, there were no significant changes between dietary treatments on percent of slaughter weight. It was slightly increased with herbal extract supplementation. Chicks fed the mixture of garlic and thyme $(2 \%+0.4 \%)$ had the highest dressing percent compared to the control group. Percent of giblets was equal to or less than the control group. At 5 weeks of age, different levels of garlic and thyme supplementation significantly affected the carcass traits. The highest percent of slaughter $(75.82 \%)$ was observed in group 5 that was fed $0.4 \%$ thyme. 
Table (5). Effect of dietary garlic and thyme powder supplementation on carcass characteristics of broiler chicks at 3 weeks of age (Means \pm S.E).

\begin{tabular}{|c|c|c|c|c|c|c|c|}
\hline \multirow{2}{*}{ Treatments $^{1}$} & \multirow{2}{*}{ Dressing (\%) } & \multicolumn{2}{|c|}{ Giblets (\%) } & & \multicolumn{3}{|c|}{ lymphoid organs (g) } \\
\hline & & Liver & Heart & Gizzard & Spleen & Bursa & Thymus \\
\hline T1 & $66.23 \pm 0.50$ & $3.05^{\mathrm{a}} \pm 0.03$ & $0.66^{b} \pm 0.03$ & $2.90^{\mathrm{a}} \pm 0.08$ & $4.67^{\mathrm{ab}} \pm 0.88$ & $1.26^{\mathrm{C}} \pm 0.01$ & $2.94^{\mathrm{d} 2,3} \pm 0.01$ \\
\hline $\mathbf{T 2}$ & $68.83 \pm 0.74$ & $2.71^{\mathrm{ab}} \pm 0.05$ & $0.65^{b} \pm 0.01$ & $2.42^{b c} \pm 0.04$ & $4.33^{\mathrm{ab}} \pm 0.33$ & $1.34^{b} \pm 0.01$ & $3.12^{c} \pm 0.01$ \\
\hline $\mathbf{T 3}$ & $67.38 \pm 1.57$ & $2.62^{b} \pm 0.03$ & $0.76^{a} \pm 0.01$ & $2.74^{\mathrm{a}} \pm 0.05$ & $4.00^{b} \pm 14$ & $1.23^{d} \pm 0.01$ & $2.87^{\mathrm{e}} \pm 0.01$ \\
\hline T4 & $69.31 \pm 1.31$ & $2.62^{b} \pm 0.08$ & $0.61^{c} \pm 0.03$ & $2.42^{b c} \pm 0.08$ & $6.00^{\mathrm{a}} \pm 17$ & $1.42^{\mathrm{a}} \pm 0.01$ & $3.31^{\mathrm{a}} \pm 0.01$ \\
\hline T5 & $73.35 \pm 4.59$ & $2.73^{\mathrm{ab}} \pm 0.04$ & $0.69^{b} \pm 0.02$ & $2.57^{b} \pm 0.05$ & $4.33^{\mathrm{ab}} \pm 0.67$ & $1.35^{b} \pm 0.01$ & $3.16^{\mathrm{b}} \pm 0.01$ \\
\hline T6 & $70.86 \pm 2.74$ & $2.63^{b} \pm 0.07$ & $0.62^{c} \pm 0.01$ & $2.33^{c} \pm 0.12$ & $4.67^{\mathrm{ab}} \pm 0.67$ & $1.42^{\mathrm{a}} \pm 0.01$ & $3.31^{\mathrm{a}} \pm 0.01$ \\
\hline $\mathbf{T 7}$ & $71.52 \pm 0.59$ & $2.55^{b} \pm 0.03$ & $0.62^{c} \pm 0.01$ & $2.52^{b} \pm 0.05$ & $5.00^{\mathrm{ab}} \pm 0.88$ & $1.42^{\mathrm{a}} \pm 0.01$ & $3.32^{\mathrm{a}} \pm 0.01$ \\
\hline
\end{tabular}

Table (6). Effect of dietary garlic and thyme powder supplementation on carcass characteristics of broiler chicks at 5 weeks of age (Means \pm S.E).

\begin{tabular}{|c|c|c|c|c|c|c|c|}
\hline \multirow{2}{*}{ Treatments $^{1}$} & \multirow{2}{*}{$\begin{array}{l}\text { Dressing } \\
\quad(\%)\end{array}$} & \multicolumn{2}{|c|}{ Giblets (\%) } & \multicolumn{4}{|c|}{ lymphoid organs (g) } \\
\hline & & Liver & Heart & Gizzard & Spleen & Bursa & Thymus \\
\hline T1 & $75.68^{b} \pm 4.73$ & $1.94 \pm 0.05$ & $0.54^{\mathrm{a}} \pm 0.01$ & $1.56^{\mathrm{ab}} \pm 0.06$ & $6.67^{c} \pm 0.33$ & $3.13^{d} \pm 0.01$ & $7.30^{62,3} \pm 0.01$ \\
\hline $\mathbf{T} 2$ & $73.59^{b} \pm 1.23$ & $1.92 \pm 0.03$ & $0.42^{b} \pm 0.02$ & $1.59^{\mathrm{ab}} \pm 0.03$ & $7.33^{b c} \pm 0.88$ & $3.28^{c} \pm 0.01$ & $7.65^{\mathrm{ab}} \pm 0.01$ \\
\hline T3 & $78.83^{\mathrm{a}} \pm 3.59$ & $1.90 \pm 0.03$ & $0.47^{\mathrm{ab}} \pm 0.01$ & $1.65^{\mathrm{a}} \pm 0.03$ & $8.00^{b c} \pm 0.58$ & $3.13^{d} \pm 0.01$ & $7.29^{b} \pm 0.01$ \\
\hline T4 & $71.48^{b} \pm 1.80$ & $1.90 \pm 0.02$ & $0.46^{b} \pm 0.01$ & $1.51^{b} \pm 0.05$ & $7.67^{b c} \pm 0.33$ & $3.34^{b} \pm 0.01$ & $7.80^{\mathrm{a}} \pm 0.01$ \\
\hline T5 & $75.82^{b} \pm 3.28$ & $1.99 \pm 0.03$ & $0.49^{\mathrm{ab}} \pm 0.01$ & $1.53^{\mathrm{ab}} \pm 0.04$ & $8.33^{b c} \pm 0.67$ & $3.27^{c} \pm 0.01$ & $7.30^{b} \pm 0.01$ \\
\hline T6 & $73.67^{b} \pm 3.57$ & $1.92 \pm 0.05$ & $0.44^{b} \pm 0.01$ & $1.53^{\mathrm{ab}} \pm 0.04$ & $11.00^{\mathrm{a}} \pm 0.02$ & $3.37^{\mathrm{a}} \pm 0.01$ & $7.72^{\mathrm{a}} \pm 0.01$ \\
\hline T7 & $72.1^{b} \pm 1.75$ & $1.91 \pm 0.03$ & $0.47^{\mathrm{ab}} \pm 0.05$ & $1.52^{\mathrm{ab}} \pm 0.03$ & $9.67^{\mathrm{ab}} \pm 0.33$ & $3.38^{\mathrm{a}} \pm 0.01$ & $7.85^{\mathrm{a}} \pm 0.01$ \\
\hline
\end{tabular}

${ }^{I} T_{1} ;$ control, $T_{2}$; control $+1 \%$ Garlic, $T_{3} ;$ control $+2 \%$ Garlic, $T_{4} ;$ control $+0.2 \%$ Thyme, $T_{5} ;$ control $+0.4 \%$

Thyme, $T_{6}$; control + mixture of $(1 \%$ Garlic $+0.2 \%$ Thyme $)$ and $T_{7}$; control + mixture of $(2 \%$ Garlic $+0.4 \%$ Thyme $)$.

${ }^{2}$ means \pm S.E. of 3 replicates / treatment.

${ }^{3} a, b, c \ldots . . . . . e t c:$ Means within the same column with different superscripts are significantly different $(P<0.05)$.

Lymphoid organs (spleen, bursa and thymus) were significantly increased with different supplementation levels except chicks fed the supplementation of $2 \%$ garlic powder at 3 and 5 weeks. The highest lymphoid organs weights were at chicks fed $0.2 \%$ thyme powder compared to the control group at 3 weeks. With the increasing of age and supplementation, groups fed both mixtures of garlic and thyme $(1 \%$ garlic $+0.2 \%$ thyme and $2 \%$ garlic $+0.4 \%$ thyme $)$ have the highest relative lymphoid organs weights compared to the control group.

The same results were reported by Lee et al. (2003) and Mansoub and Myandoab (2011) who noted that the carvacrol, one of the major substances in thyme has stimulatory effects on pancreatic secretion by increasing the secretions of digestive enzymes, thus more amounts of nutrients like amino acids can be digested and absorbed from the digestive tract and thereby improved carcass traits.

On the contrary, Carrijo et al. (2005), Gbenga et al. (2009), Kirkpinar et al. (2011) and Toghyani et al. (2011) noted that there were no significant effects of garlic supplementation on carcass traits. Elagib et al. (2013) noted that both bursa and thymus showed no significant difference between the different treatments (3 and 5\% garlic powder). Spleen weight was significantly decreased in birds fed 3 and $5 \%$ garlic level compared to the control group.

\section{Serum biochemical parameters:}

Experimental results regarding the effect of garlic (1 and 2\%) and thyme $(0.2$ and $0.4 \%)$ single or mixed at 3 and 5 weeks of age on serum biochemical parameters are shown in Tables (7 and 8). At 3 weeks of age, results indicated that both herbal plants significantly $(\mathrm{P} \leq 0.05)$ increased total protein 
values and albumin/ globulin ratio $(\mathrm{A} / \mathrm{G})$ ratio compared to the control diet. The highest total protein value was obtained with chicks fed $1 \%$ garlic powder $(2.73 \mathrm{~g} / \mathrm{dl})$ in comparison with 2.24 at the control group. The highest A/ G ratio was for chicks fed garlic at the level of $2 \%$, followed by chicks fed $0.2 \%$ thyme.

Table (7). Effect of dietary garlic and thyme powder supplementation on some blood components at 3 weeks of age (Means \pm S.E).

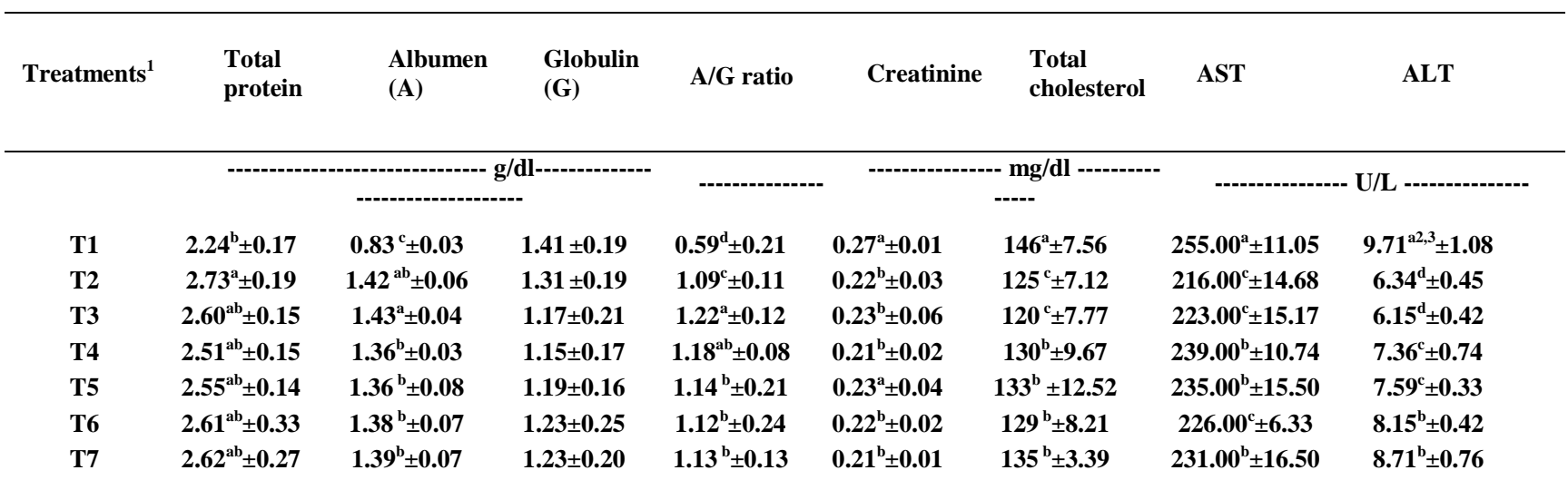

${ }^{T} T_{1}$; control, $T_{2}$; control $+1 \%$ Garlic, $T_{3} ;$ control $+2 \%$ Garlic, $T_{4} ;$ control $+0.2 \%$ Thyme, $T_{5} ;$ control $+0.4 \%$

Thyme, $T_{6}$; control + mixture of $(1 \%$ Garlic $+0.2 \%$ Thyme $)$ and $T_{7}$; control + mixture of $(2 \%$ Garlic $+0.4 \%$ Thyme $)$.

${ }^{2}$ means \pm S.E. of 3 replicates / treatment.

${ }^{3} a, b, c \ldots \ldots . . . e t c:$ Means within the same column with different superscripts are significantly different $(P<0.05)$.

Table (8). Effect of dietary garlic and thyme powder supplementation on some blood components at 5 weeks of age (Means \pm S.E).

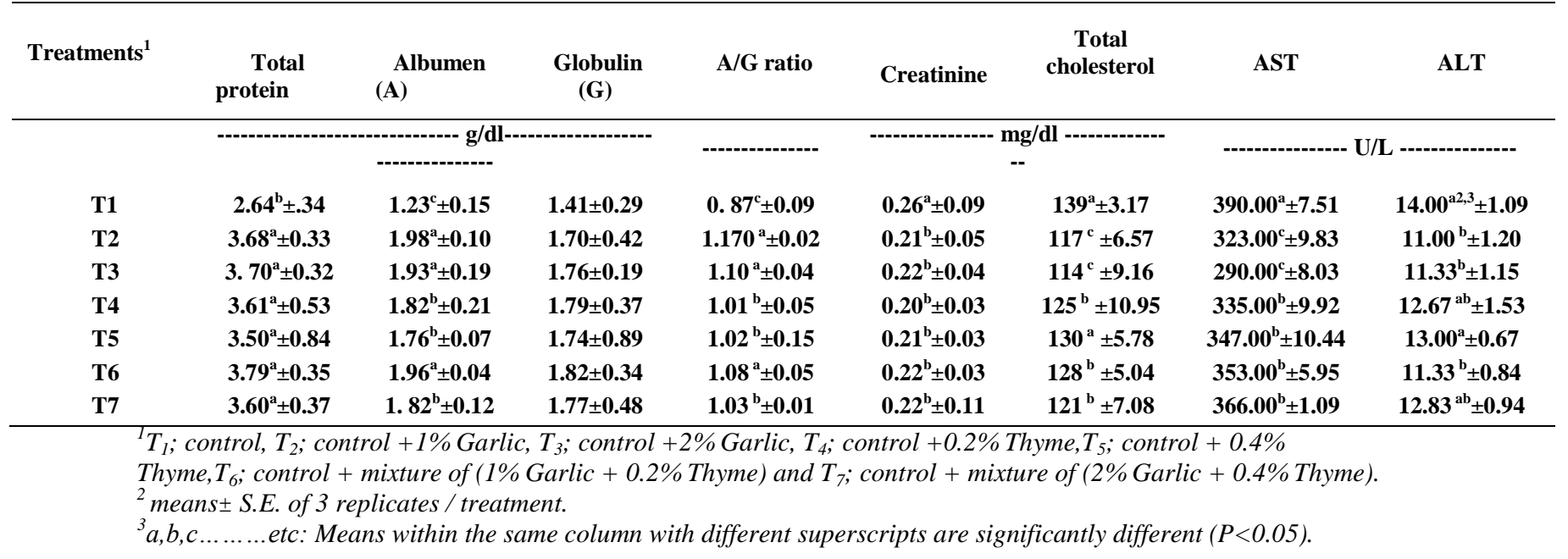

The same trend was noticed by Platel et al. (2004) who found that garlic increases the alkalinephosphatase enzyme activity. Thyme also, has antibacterial and antifungal activity (Basilico and Basilico, 1999 and Vincent Hv, 2002). In addition, thymol (the main component of thyme) has an antioxidant activity. Due to these facts, the immune system improving activities of garlic and thyme could be predicted.

At 5 weeks of age, data followed the same pattern. Garlic and thyme powder significantly $(\mathrm{P} \leq 0.05)$ increased total protein, albumin, globulin and $\mathrm{A} / \mathrm{G}$ ratio. No significant changes in total protein values were observed for chicks fed the control diet mixed with garlic or thyme powder. The highest total protein value was 3.79 at $\mathrm{T}_{6}$ compared to 2.64 at the control group.

$\mathrm{A} / \mathrm{G}$ ratio also, is an indicator for the immune response of chicks. It was significantly $(\mathrm{P} \leq 0.05)$ increased with the supplementation of herbal plants. The best $A / G$ ratio was for groups fed garlic in comparison with the control group. At 3 weeks of age, data indicated that creatinine level and total cholesterol were significantly decreased with garlic or thyme supplementation in comparison with the control group. The same results were observed at 5 weeks of age. 


\section{Abou-Elnaga et al.}

These results agree with Qureshi et al. (1983), Lee et al. (2004), Case et al. (1995), Ao et al. (2011), Singh et al. (2015), Mansoub and Myandoab (2011) and Toghyani et al. (2011) who indicated that compounds containing an allyl- disulfide or allyl - sulfhydryl group were most likely responsible for the inhibition of cholesterol synthesis by garlic.

Our results about cholesterol were contrary to some studies; Bolukbasi et al. (2006), Figen et al. (2011) and Al- kassie (2009) found that garlic or thyme supplementation increased total cholesterol. But, on the other hand, Najafi and Torki (2010) and Carrijo et al. (2005) did not report any alternation in serum levels of cholesterol after feeding broiler chicks with a diet containing up to $1 \%$ garlic powder.

This may be due to the reduction of synthetic enzyme activities. Garlic has a dose- dependent inhibition effect on hepatic $\beta$ - hydroxyl- $\beta$ - methylglutaryl co - enzyme A (HMG- CoA) reductase (which regulates the cholesterol bio- synthesis in liver), cholesterol $7 \alpha$-hydroxylase and fatty acid synthetase (Queshi et al., 1983). They reported that diets containing an equivalent of 1, 2, 4, 6 and $8 \%$ garlic paste reduced serum cholesterol by $18,21,21,24$ and $25 \%$, respectively.

Results indicated that garlic and thyme supplementation decreased serum aspartate aminotransferase (AST) and alanine aminotransferase (ALT) enzymes. The lowest AST and ALT values were noticed at groups fed both levels of garlic followed by both levels of thyme compared to the control group after 3 weeks. Similar to current findings Augusti et al. (2001) observed that lipid parameters and enzyme activities (SGOT, SGPT and alkaline phosphatase) in serum of rats decreased significantly when they were fed diet containing $5 \%$ garlic.

Contrary to the current findings Kung-chi et al. (2006) did not report any influence of dietary garlic oil supplement on serum biochemical analysis in rats including SGOT and SGPT levels. Also, Toghyani et al. (2011) found that the highest level of SGPT (3.1) was measured in broilers receiving antibiotic (3 $\mathrm{mg} / \mathrm{kg}$ falvophospholipol) and the lowest level (1.1) was measured in broilers fed $4 \mathrm{~g} / \mathrm{kg}$ cinnamon. Whereas, SGPT levels was not influenced by dietary garlic supplementation (2 and 4g/ kg diet; $1.9,1.7$ $\mathrm{U} / \mathrm{L}$, respectively) and was not exceed the normal range of the control diet $2.1 \mathrm{U} / \mathrm{L}$.

These enzymes are relatively specific indicator of acute liver cell damage and pathological manifestation of liver function. When such damage occurs, serum AST and serum ALT are released from the liver cells into the blood steam, thus any abnormal increases in their concentration could imply liver malfunction.

\section{Economical efficiency:}

Data pertaining to dietary garlic and thyme supplementations on the relative economical efficiency (REE) are presented in Table (9). In comparison with the control group (100\%); groups fed garlic at all

Table (9). Effect of dietary garlic and thyme powder supplementation on the economic efficiency of the experimental diets at 35 days.

\begin{tabular}{|c|c|c|c|c|c|c|c|}
\hline \multirow{2}{*}{ Item } & \multicolumn{7}{|c|}{ Treatments ${ }^{1}$} \\
\hline & $\mathrm{T}_{1}$ & $\mathrm{~T}_{2}$ & $\mathrm{~T}_{3}$ & $\mathrm{~T}_{4}$ & $\mathrm{~T}_{5}$ & $\mathrm{~T}_{6}$ & $\mathrm{~T}_{7}$ \\
\hline Initial body weight, $(\mathrm{g})$ & 40 & 40 & 40 & 40 & 40 & 40 & 40 \\
\hline Final body weight, (kg) & 2.12 & 2.16 & 2.04 & 2.06 & 2.14 & 2.13 & 2.20 \\
\hline Body weight gain, $(\mathrm{kg})$ & 2.08 & 2.12 & 2.00 & 2.02 & 2.10 & 2.09 & 2.16 \\
\hline Total revenue,(L.E) ${ }^{2}$ & 33.28 & 33.92 & 32 & 32.32 & 33.60 & 33.44 & 34.56 \\
\hline Feed intake, $(\mathrm{kg})$ & 3.58 & 3.53 & 2.94 & 2.99 & 2.97 & 2.89 & 3.04 \\
\hline Price of $\mathrm{kg}$ feed,(L.E) ${ }^{3}$ & 3.45 & 3.80 & 4.15 & 3.47 & 3.49 & 3.82 & 4.19 \\
\hline Feed cost, (L.E) & 12.35 & 13.41 & 12.20 & 10.38 & 10.37 & 11.04 & 12.74 \\
\hline Net revenue,(L.E) ${ }^{4}$ & 20.93 & 20.51 & 19.80 & 21.94 & 23.23 & 22.40 & 21.82 \\
\hline Economical efficiency ${ }^{5}$. & 168 & 153 & 162 & 211 & 224 & 203 & 171 \\
\hline Relative economical & 100 & 91 & 96 & 125.60 & 133 & 120 & 101 \\
\hline
\end{tabular}

${ }^{1} T_{1} ;$ control, $T_{2} ;$ control $+1 \%$ Garlic, $T_{3} ;$ control $+2 \%$ Garlic, $T_{4} ;$ control $+0.2 \%$ Thyme, $T_{5} ;$ control $+0.4 \%$ Thyme, $T_{6} ;$

control + mixture of (1\% Garlic + 0.2\% Thyme) and $T_{7}$; control + mixture of ( $2 \%$ Garlic $+0.4 \%$ Thyme).

${ }^{2}$ total revenue $=$ body weight gain, $(\mathrm{kg}) \times$ price of one $\mathrm{kg}$ live body weight.

${ }^{3}$ Price of one $\mathrm{kg}$ live body weight was $16 \mathrm{~L}$.E. Price of one $\mathrm{kg}$ garlic powder $35 \mathrm{~L}$.E. Price of one $\mathrm{kg}$ thyme powder

20 L.E.

${ }^{4}$ Net revenue $=$ Total revenue - Feed cost .

${ }^{5}$ Economical efficiency $=($ Net revenue $/$ Feed cost $) \times 100$. 
levels resulted in an increase in the feeding cost when compared to the control group. The best improvement was reported for chicks fed the control diet supplemented with $0.4 \%$ thyme powder; being $133 \%$ followed by those fed $0.2 \%$ thyme powder $(125 \%)$.

\section{REFERENCES}

Adeniyi, B. A., F. S. Oluwole and F. M. Anyiam (2006). Antimicrobial and antiulcer activities of methanol extract of Allium sativum on helicobacter pylori. J. Boil. Sci., 6: 521- 526.

Afsharmanesh M, Sadeghi Ronizi B. and Mehrabadi M. (2008). The comparison of natural feed additives ( garlic and yogurt )with antibiotic growth promoters on broiler performance . National conference livestock and poultry industry of Golestan province, Des. 208, 25 - 36

Agarwal, K.C. (1996). Therapeutic action of garlic constituents. Med. Res. Rev. 16 (1): 111 - 124.

Aji, S.B., K. Ignatius, A.A.Y. Ado, J.B. Nuhu, A. Abdulkarim, U. Aliyu, M.B. Gambo, M.A. Ibrahim, H. Abubakar, M.M. Bukar, M. Hama, Adama, Imam and P.T. Numan (2011). Effects of feeding Onion ( Allium cepa) and Garlic (Allium sativum) on Some Performance Characteristics of Broiler Chickens. Res. J. of Poult. Sci. 4 (2): 22- 27.

$\mathrm{Al}$ - Kassie, G. A. M. (2009). Influence of two plant extracts derived from Thyme and Cinnamon on broiler performance. Pakistan Vet. J, 29(4): $169-173$.

Amagase, H., B.L. Petesch, H. Matsuura, S. Kasuga and Y. Itakura (2001). Intake of garlic and its bioactive components. J. Nutr. 131(S3): 955 S - 962 S.

Ankri, S. and D. Mirelman (1999). Antimicrobial properties of allicin from garlic. Microbes Infect., 1: $125-129$.

Ao, X., J. S., Yoo, T. X. Zhou, J. P. Wang, Q. W. Meng, L. Yan, J. H. Cho and I. H. Kim (2011). Effects of fermented garlic powder supplementation on growth performance, blood profiles and breast meat quality in broilers. Live Stock Sci., 141: 85-89.

Augusti , K.T., A., Narayanan, L.S., Pillai, R.S., Ebrahim, R., Sivadasan , K.R., Sindhu , I., Subha, S., Abdeen and S,S., Nair, 2001.

Beneficial effects of garlic ( Allium sativum Linn) on rats fed with diets containing cholesterol and either of the oil seeds , coconuts or groundnuts. Indian J. Exp. Biol., 39: 660 - 667.

Basilico, M.Z. and J.C. Basilico (1999). Inhibitory effects of some spice essential oils on Aspergillusochraceus NRRL 3174 growth and ochratoxin A production. Letters: Applied Microbiology 29: 238- 241.

Bolukbasi, S.C., M.K. Erhan and A.O. Zkan, (2006). Effect of dietary thyme oil and vitamin E on growth, lipid oxidation, Meat fatty acid composition and serum lipoproteins of broilers. South African J. Anim. Sci., 36 (3).

Carrijo,A.S., L.A., Madeira, J.R., Sartori, A.C.,Pezzato, J.C., Goncalves, V.C., Cruz, K.V., Kuibida and D.F., Pinheiro, (2005). Powdered garlic in the alternative feeding of broiler chickens. Pesq. Agropec . Bras. $40,673-679$.

Case,G.L., L., He, H. Mo, and C.E., Elson (1995). Induction of geranyl pyrophosphate activity by cholesterol - suppressive isoprenoids. Lipids, 30: 357 - 359.

Demir, E., K. Kilinc, Y. Yildirim, D. Fatma and H. Eseceli (2008). Comparative effects of mint, sage, thyme and flavomycin in wheat-based broiler diets. Archiva Zootechnica 11, 3: 54-63.

Duncan,D.B. (1955). Multiple range test and multiple $F$ test. Biometrics, $11: 1-42$.

Elagib, H. A. A., W. I. A. El-Amin., K.M. El-amin and H. E. E. Malik, 2013. Effect of dietary garlic supplementation as feed additive on broiler performance and blood profile. J. Anim. Sci. Adv., 3(2): 58-64.

Fadlalla, I. M. T., B. H. Mohamed and A.O. Bakhiet, 2010. Effect of feeding garlic on the performance and immunity of broiler. Asian J. Poul. Sci., 4 (4): 182-189. 
Figen, K. k., H. Boraunlu and G. Ozdemir, 2011. Effects of oregano and garlic essential oils on performance, carcass, organ, blood characteristics and intestinal microflora of broilers.Livestock Sci., $137: 219-225$.

Gbenga, E.O., E.A., Oluwatoyin, N.F.,Adebowale and V.A., Ayodeji, (2009). Response of broiler chickens in terms of performance and meat quality to garlic (Allium sativum) supplementation. Afric. J. Agric. Res. 4 (5), $511-517$.

Heady, E. O. and Jensen, H. R. (1954). Farm Management Economics. Pentice - Hall Inc. Englewood Cliffs, N.J., USA.

Hertrampf, J.W. (2001). Alternative antibacterial performance promoters. Poul. Inter. 40: 50 - 52 .

Javed,.M., F.R. Durrani, A. Hafeez, R. Khan and I. Ahmad (2006). Extract of plant mixture on carcass quality of broiler chicks. Journal of Agricultural and Biological Science . 1:115-121.

Javandel, F, B. J. Navidshad Seifdavati, G.H. Pourrahimi and S. Baniyaghoub (2008). The favorite dosage of garlic meal as a feed additive in broiler chickens ratios. Pak. J. Biol. Sci. 11 (13) : $1764-$ 1749.

Kamel, C.T. (2001). Modes of action and roles of plant extracts in non-ruminants. Recent advances in animal nutrition: P.C. Garnssworthy and J. Wiseman, Nottingham Univ. Press, Nottingham, UK. Nutraceuticals, 19- 21.

Kirkpinar, F., H.B. Unlu and G. Ozdemir (2011). Effects of oregano and garlic essential oils on performance, carcass organ, blood characteristics and intestinal microflora of broilers. Livestock Sci. 137 (2011) 219- 225.

Kirkpinar, F., H. B. Unlu ., M. Serdaroglu, and G. Y. Turp (2014). Effects of dietary oregano and garlic essential oils on carcass characteristics, meat composition, colour, $\mathrm{pH}$ and sensory quality of broiler meat. Brit. Poul. Sci., 55 (2) 157- 166.

Kumar, M., R.S. Choudhary and J.K. Vaishnav (2005). Effect of supplemental prebiotic, probiotic and turmeric in diet on the performance of broiler chicks during summer. Indian Journal of Poultry Science, 40 (2) : $137-141$.

Kung-Chi, C., Y. Mei-Chin and C. Wan-Ju (2006). Effect of diallyl trisulfide - rich garlic oil on blood coagulation and plasma activity of anticoagulation factors in rats. Food Chem. Toxicol. 45: 502-507.

Lee, K.W., H. Everts, H.J. Kappert, M. Frehner, R. Losa and A.C. Beynen (2003). Effects of dietary essential oil components on growth performance, digestive enzymes and lipid metabolism in female broiler chickens. Br. Poult. Sci., 44: 450 - 457.

Lee,K.W., H., Everts, H.J., Kappert, H. Wouterse, M. Frehner and A.C. Beynen (2004). Cinnamaldehyde, but not thymol, counteracts the carboxymethyl cellulose - induced growth depression in female broiler chickens. Int. J. Poult. Sci., 3 (9): $609-612$.

Mansoub, N. H. and M. A. M. Nezhady (2011). Effect of garlic, thyme and yogurt compared to antibiotics on performance, immunity and some blood parameters of broiler chickens. Indian of Anim. Sci., 81 (12): 1197-1200.

ManSoub, N.H. and M.P.Y. Myandoab (2011). The effect of different levels of thyme on performance, carcass traits and blood parameters of broilers.Scholars Research Library Annals of Biological Research, 2(4): 379-385.

Mikaili, P., M. A. M. Nezhady., J. Shayegh and M.H. Asghari (2010). Study of antinociceptive effect of thymus Vulgaris and foeniculum Vulgaris essential oil in mouse. Inter. J. of Academic Res. 2(6): 374376.

Najafi, P. and M. Torki (2010). Performance, blood metabolites and immune competence of broiler chicks fed diets included essential oils of medicinal herbs. J. Anim. and Vet. Adv. 9 (7) : 1164 - 116

North , M.O. (1984). Commercial chicken production manual. $3^{\text {rd }}$, The AVI, Publishing co. Inc., West port, Connecticut, U.S.A.

NRC (1994). Nutrient Requirements of Poultry. 9th Rev. ed. National Academy press, Washington, D.C. 
Onibi, E.G., E.O. Adebisi, N.A. Fajemisin, and V.A. Adetunji (2009). Response of broiler chickens in terms of performance and meat quality to garlic (Allium sativum) supplementation. African J. Agric. Res. 4 (5): $511-517$.

Platel, K. and K. Srinivasan (2004). Stimulant action of spices. A myth or reality. Indian J. Medicinal Research, 119: 167 - 179.

Prasad, G., V.A. Laxdal, M. Yu and B.L. Raney (1995). Antioxidant activity of Allicin, an active principle in garlic. Mol. Cell. Biochem., 148, 183- 189.

Qureshi, A.A., Z.Z. Din, N. Abuirmeileh, W.C. Burger, Y. Ahmed and C.E. Elson (1983). Suppression of avian hepatic lipid metabolism by solvent extracts of garlic - Impact on serum lipid. Journal of nutrition , 113: $1746-1755$.

Raeesi, M., S.A. A.Hoeini-Aliabad, A. Roofchaee, Zare Shahneh and S. Pirali (2010). Effect of periodically use of garlic ( allium sativum) powder on performance and carcass characteristics in broiler chickens. World Academy of Science, Engine. Techno. 68: 1213 - 1219.

Rahardja,D.P., M. R.Hakim, W. Paliding and V. S. Lestari (2010). Hypocholesterolemic effect of garlic powder in laying hen Low cholesterol egg . J. Indonesian Trop. Anim. Agric., 35: 16 - 21.

Saeid, J. M.; A.B. Mohamed and M.A. Al-Baddy (2013). Effect of adding garlic powder and black seed in feed on broiler growth performance and intestinal wall structure. J. Natural Sci. Research 3 (1).

Singh, J., A.P.S. Sethi, S.S. Sikka, M.K. Chatli, and P. Kumar (2015). Effect of sun dried whole bulb garlic powder on growth, carcass characteristics and meat quality of commercial broilers. Indian J. Anim. Sci. , 85(1): 67-71.

SPSS (2011). SPSS 11.0 for Windows. SPSS Inc., Chicago.

Standardization Administration of China (2005). National feed Industry Standards for Enzyme Assays in China.

Sterling, S.J., R.D. Eagling (2001). Agronomic and allicin yield of Australian grown garlic (Allium sativum). Acta Hortic. 555: 63 - 73.

Tabari, D.G., M.R. Rezrani, M.J. Zamiri and M. Dadpasand (2013). The effect of oregano and thyme based essential oils and beta-glucanase on performance and nutrients digestibility in broiler chicks fed barley-based diets. J. Vet. Research, 68 (3): 241-248. 32 ref.

Tapiero, H., D.M. Townsend and K.D. Tew (2004). Organosulfur compounds from alliaceae in the prevention of human pathologies. Biomed. Pharmacother., 58: 183 - 193.

Toghyani, M., M. Taghyani, A. Gheisari, G. Ghalamrari and S.E. Saied (2011). Evaluation of cinnamon and garlic as antibiotic growth promoter substitutions on performance, immune responses, serum biochemical and hematological parameters in broiler chicks. Livestock Sci., 138: 167-173.

Toghyani, M., M. Tohidi, A.A. Gheisari, and S.A. Tabeidian (2010). Performance, immunity, serum biochemical and hematological parameters in broiler chicks fed dietary thyme as alternative for an antibiotic growth promoter. African J. Biotech. 9 (40): 68- 19-25.

Vincent, H.V. (2002). Carvacrol and thymol reduce swine waste odour and pathogens stability of oils. Current Microbiology $44: 38-43$.

Wegener, H.C., F. M. Aarestrup, P. Gerner - Smidt and F. Bager (1999). Transfer of antibiotic resistant bacteria from animals to man. Acta Veterinaria Scandinavica, $92: 51-57$. 
التأثيرات المفيدة لمسحوق الثوم والزعتر على الأداء الإتتاجى وصفات الذبيحة فى كتاكيت اللحم

منال كمال أبو النجا، جمال عبد الستار زناتى, عاطف محم حسن أبو عاثور و محمه فوزى عبد الحفيظ

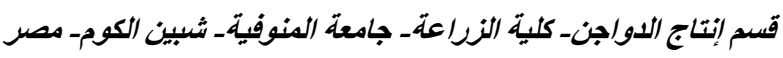

أجريت هذه التجربة لدر اسة تأثير إضافة مسحوق بعض النباتات الطبية (الثوم و الزعتر ومخاليطهما) على معدل النمو وصفات الذبيحة

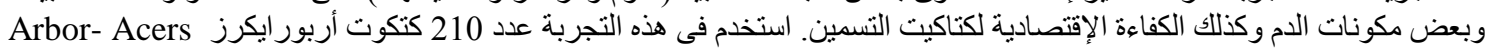

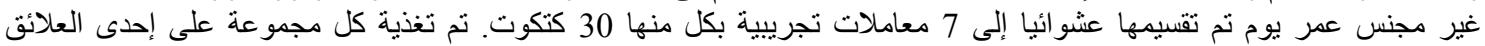

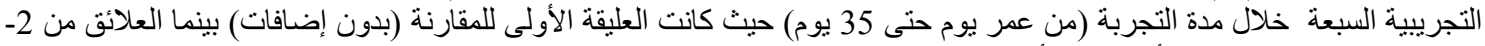

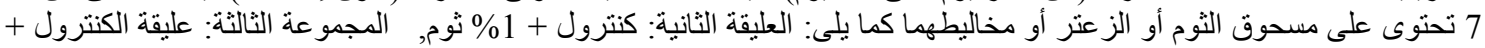

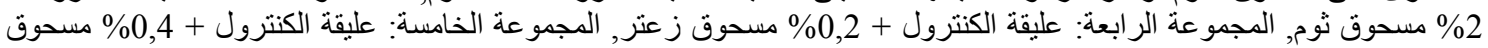

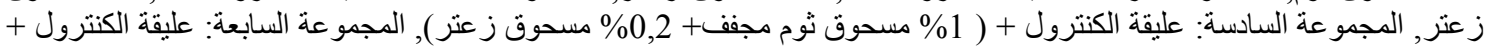

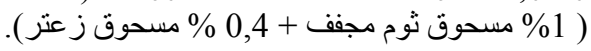

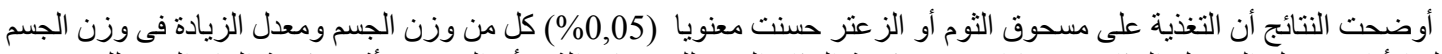

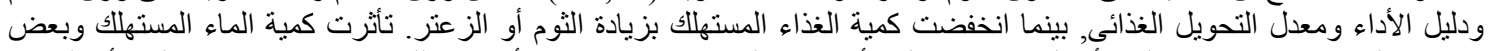

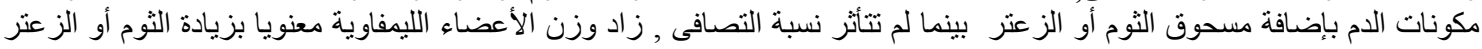
فى العلائق.

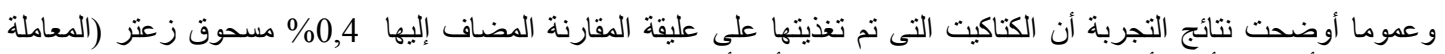

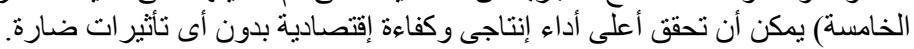

